\title{
Correction to: Future range dynamics of the red alga Capreolia implexa in native and invaded regions: contrasting predictions from species distribution models versus physiological knowledge
}

\author{
Philipp Laeseke (D) Brezo Martínez - Andrés Mansilla - Kai Bischof
}

Published online: 23 June 2021

(C) The Author(s) 2021

\section{Correction to: Biol Invasions (2020) 22:1339-1352 https://doi.org/10.1007/s10530-019-02186-4}

The article "Future range dynamics of the red alga Capreolia implexa in native and invaded regions: contrasting predictions from species distribution models versus physiological knowledge", written by Philipp Laeseke, Brezo Martínez, Andrés Mansilla and Kai Bischof, was originally published Online First without Open Access. After publication in volume 22, issue 4, page 1339-1352 the author decided to opt for Open Choice and to make the article an Open Access publication. Therefore, the copyright of the article has

The original article can be found online at https:// doi.org/10.1007/s10530-019-02186-4.

P. Laeseke $(\bowtie) \cdot K$. Bischof

Department of Marine Botany, University of Bremen,

Bremen, Germany

e-mail: philipp.laeseke@uni-bremen.de

B. Martínez

Universidad Rey Juan Carlos, Área de Biodiversidad y Conservación, Madrid, Spain

A. Mansilla

Laboratory of Antarctic and Sub-Antarctic Marine

Ecosystems (LEMAS), Institute of Ecology and

Biodiversity (IEB), University of Magallanes,

Punta Arenas, Chile been changed to (C) The Author(s) 2020 and the article is forthwith distributed under the terms of the Creative Commons Attribution 4.0 International License, which permits use, sharing, adaptation, distribution and reproduction in any medium or format, as long as you give appropriate credit to the original author(s) and the source, provide a link to the Creative Commons licence, and indicate if changes were made. The images or other third party material in this article are included in the article's Creative Commons licence, unless indicated otherwise in a credit line to the material. If material is not included in the article's Creative Commons licence and your intended use is not permitted by statutory regulation or exceeds the permitted use, you will need to obtain permission directly from the copyright holder. To view a copy of this licence, visit http://creativecommons.org/ licenses/by/4.0. Open access funding enabled and organized by Projekt DEAL.

The original article has been corrected.

Open Access This article is licensed under a Creative Commons Attribution 4.0 International License, which permits use, sharing, adaptation, distribution and reproduction in any medium or format, as long as you give appropriate credit to the original author(s) and the source, provide a link to the Creative Commons licence, and indicate if changes were made. The images or other third party material in this article are included in the article's Creative Commons licence, unless indicated otherwise in a credit line to the material. If material is not included in the article's Creative Commons licence and your intended use is not permitted by statutory regulation or exceeds the permitted use, you will need to obtain permission directly 
from the copyright holder. To view a copy of this licence, visit http://creativecommons.org/licenses/by/4.0/.
Publisher's Note Springer Nature remains neutral with regard to jurisdictional claims in published maps and institutional affiliations. 